\title{
CHRONOPOTENTIOMETRY OF SOLUTIONS CONTAINING SODIUM IODIDE AND IODINE IN DIMETHYLSULPHOXIDE*
}

\author{
M. C. Giordano, J. C. BazÁn and A. J. ArviA \\ Instituto Superior de Investigaciones, Facultad de Química y Farmacia, \\ Universidad Nacional de La Plata, La Plata, Argentina
}

\begin{abstract}
Chronopotentiometric waves of solutions of sodium iodide, and sodium iodide with added iodine in dimethylsulphoxide, were determined on platinum electrodes. Sodium perchlorate was used as supporting electrolyte. The concentration range was from $2 \times 10^{-8}$ to $4 \times 10^{-2} \mathrm{M}$ and the temperature from $25 \cdot 0$ to $45 \cdot 0^{\circ} \mathrm{C}$.

The anodic waves exhibit two well-defined steps characterized by definite transition times, while only one step is observed for the cathodic waves given by the solutions with added iodine. The cathodic waves are irreversible. The first anodic wave shows a larger irreversibility than the second. The results are discussed in comparison with previous information gathered for the same systems by employing a platinum rotating disk electrode.

Diffusion coefficients for tri-iodide and iodide ions in solutions of DMSO obtained from chronopotentiometry are in agreement with those earlier reported derived from the rotating disk electrode.

Résumé- Les ondes chronopotentiométriques des solutions d'iodure de sodium et d'iodure de sodium avec addition d'iode dans le diméthylsulfoxyde ont été étudiées en employant le perchlorate de sodium comme électrolyte support. Les expériences ont été effectuées à des concentrations de $2 \cdot 10^{-1}$ a $4 \cdot 10^{-1} \mathrm{M}$ et des temperatures de 25,0 a $45,0^{\circ} \mathrm{C}$.

Les ondes anodiques montrent deux échelons bien distincts caractérisćes par des temps detransition définis, tandis qu'on a observé un seul échelon pour les ondes cathodiques. Celles-ci ne furent enregistrees que pour les solutions avec addition d'iode.

Des ondes cathodiques ont été interprétes comme des ondes irréversibles. La première onde anodique montre une plus grande irréversibilité que la deuxième. Ces résultats se discutent en comparaison avec des donnees obtenues antérieurement pour les mèmes systèmes en employant une électrode de platine à disque tournant.

Les coefficients de diffusion pour les ions tri-iodure et iodure dans les solutions de DMSO, obtenus par chronopotentiometrie presentent une bonne concordance avec ceux qui, avaient été obtenus au moyen de l'électrode à disque tournant.
\end{abstract}

Zusammenfassung - Die chronopotentiometrischen Wellen der Natriumjodid- und Natriumjodid mit Jodzusatz Losungen im Dimethylsulfoxid auf Platinelektroden wurden untersucht. Natriumperchlorat wurde als Leitelektrolyt verwendet. Die Versuche umfassten Konzentrationen von $2 \cdot 10^{-8}$ bis $4 \cdot 10^{-8} \mathrm{M}$ und Temperaturen von 25,0 bis $45,0^{\circ} \mathrm{C}$.

Die anodischen Wellen zeigen zwei deutlich definierte Stufen welche durch bestimmte Transitionszeiten charakterisiert sind, wảhrend nur eine Stufe für die kathodischen Wellen beobachtet wurde. Letztere wurden nur bei Lösungen mit Jodzusatz festgestellt.

Die kathodischen Wellen wurden als irreversible Wellen gedeutet. Die erste anodische Welle zeigt stärkere Irreversibilităt als die zweite. Diese Ergebnisse werden verglichen mit früheren Daten welche für dieselben Systeme mittels einer rotierenden Platin-Scheibenelektrode erhalten wurden.

Die Diffusionskoefizienten fïr Trijodid- und Jodidione in DMSO-Lösungen, welche mittels Chronopotentiometrie erhalten wurden, stimmen befriedigend mit den früher mittels der rotierenden Scheibenelektrode erhaltenen überein.

\section{INTRODUCTION}

THE ELECTROCHEMICAL behaviour of the tri-iodide-iodide redox system has been more extensively studied in water ${ }^{1-5}$ than in organic solvents. The solutions containing those ions exhibit a remarkable difference when the solvent is changed from water to polar organic solvents of intermediate dielectric constant. The outstanding features

\footnotetext{
- Manuscript recejved 25 July 1966.
} 
are in the anodic reactions, where the current/voltage curves obtained on platinum electrodes present two definite regions characterized by well-defined limiting currents. This peculiarity of the anodic reaction was established in preliminary experiments with solutions containing the iodide-tri-iodide couple in different organic solvents. ${ }^{6.7}$

Solutions of plain iodide and iodide with added iodine in dimethylsulphoxide (DMSO) were studied recently in this laboratory to understand their redox electrode potential as well as the kinetics of the electrode processes occurring on bright platinum rotating disk electrodes. ${ }^{8}$ From that study of the anodic and cathodic reactions, it was concluded that both processes involve the occurrence of complex electrochemical reactions with "intermediate" kinetics. Furthermore, the results allowed the evaluation of the diffusion and the activation contributions to the reaction rate, and by the detailed analysis it was possible to postulate probable reaction paths related to each process.

For further support to the previous work, we have proceeded to obtain information for the same type of solutions by means of chronopotentiometry. The potential region covered with this experimental arrangement is much narrower than the region covered before with the rotating disk electrode. Thus the kinetic data obtained under the present circumstances can be explained in terms of the reaction schemes already postulated.

\section{The electrolysis cell}

\section{EXPERIMENTAL TECHNIQUE}

The electrolysis cell is shown in Fig. 1. Its design approaches the conditions of semi-infinite linear diffusion towards a plane electrode. ${ }^{9}$ It was made with Pyrex glass and Lucite and their different parts were fitted with standard tapered joints. The working electrode consisted of a mirror-polished platinum disk of $0.709 \mathrm{~cm}^{2}$ embedded in Lucite and stuck to it with transparent epoxy-resin. The counter-electrode consisted of another platinum disk of $1.5 \mathrm{~cm}^{2}$, also stuck to a Lucite rod. Both electrodes were horizontally placed, facing each other $5 \mathrm{~cm}$ apart. Between the electrodes a sintered glass disk divided the cell into a cathodic and an anodic section. The reference electrode was at one side of the electrolysis cell and connected by means of a capillary extension, which reached to just the edge of the working electrode avoiding thus any appreciable interference in the diffusion process. The electrolysis cell was placed in an air-flowing thermostat which kept the temperature constant within $0.05^{\circ} \mathrm{C}$.

\section{Electrical circuitry}

Potential/time curves were recorded at constant current using an electrical device consisting of a $300-\mathrm{V}$ dc regulated power pack, a set of non-inductive resistors of 5000 and $100,000 \Omega$, a mercury interrupter, a precision microammeter, and either a Tektronix 545-A oscilloscope provided with a differential pre-amplifier or a potentiometric recorder. The former was employed to trace the curves up to $10 \mathrm{~s}$ while the latter was used for longer recordings.

\section{Solutions}

Two different types of solutions were prepared; (i) solutions containing sodium iodide and (ii) solutions containing sodium iodide with added iodine. Highly purified DMSO was used as solvent. ${ }^{10}$

Sodium iodide concentration was varied from $4 \times 10^{-2}$ to $2 \times 10^{-3} \mathrm{M}$, and iodine 
from $3 \times 10^{-2}$ to $2 \times 10^{-3} \mathrm{M}$. The ratio between iodine to iodide concentrations was from 2 to 20 or thereabouts. The concentration of the reacting species was evaluated using standard analytical methods.

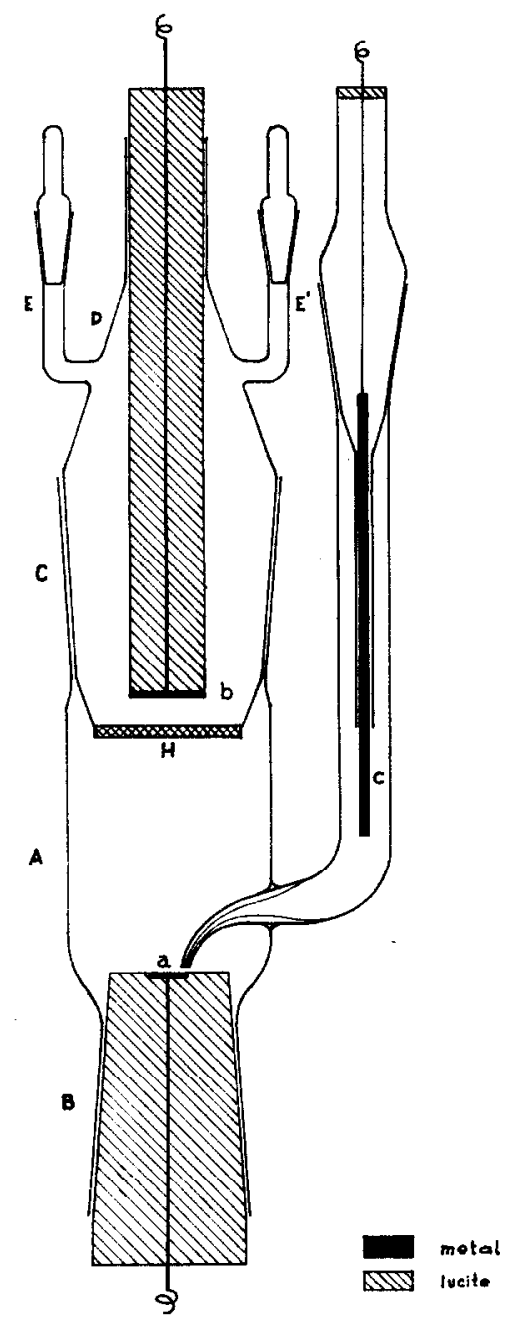

FIG. 1. Scheme of the cell.

Sodium perchlorate was employed as the supporting electrolyte for all the solutions; its concentration was varied from 0.4 to $0.8 \mathrm{M}$; its maximum value depended upon its solubility in the solvent. ${ }^{11}$ All solutions were prepared and kept continuously under a purified nitrogen atmosphere.

Experimental details

Potential/time curves were recorded covering the range of current densities from 0.6 to $3.50 \mathrm{~mA} / \mathrm{cm}^{2}$, at temperatures from 25.0 to $45.0^{\circ} \mathrm{C}$

When sodium iodide solutions were employed a silver/silver-iodide reference electrode was used. For the solutions with added iodine, a platinum electrode dipped into the same solution worked as a reference electrode. 
Between each trace at least 15 min elapsed, this being the minimum time required for the system to attain equilibrium conditions.

RESULTS

Typical potential/time curves recorded under different experimental conditions are shown in Figs. 2-8.

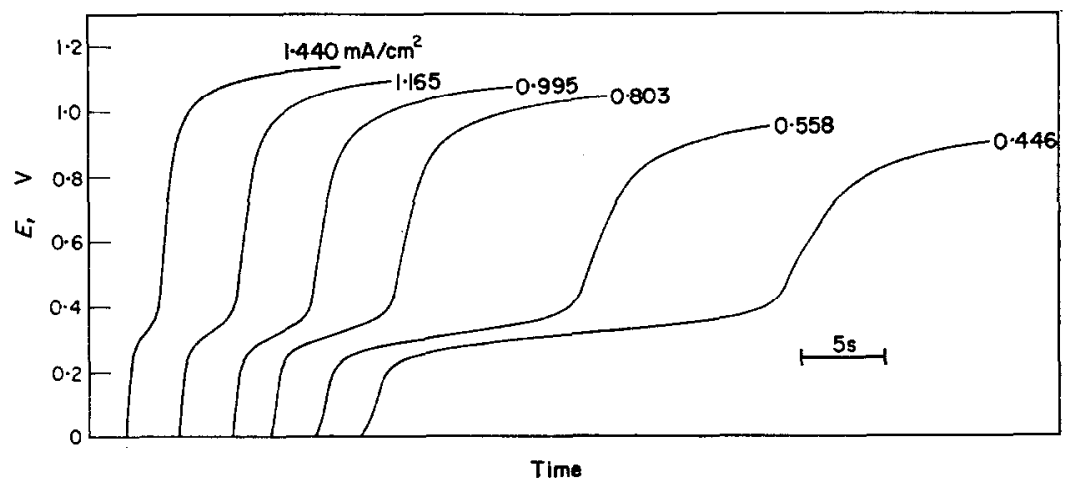

Frg. 2. Anodic potential/time curves.

[NaI], 0.0132 M; $\left[\mathrm{NaClO}_{4}\right], 0.40 \mathrm{M} ;\left[\mathrm{I}_{2}\right], 0.0090 \mathrm{M} ; 25.0^{\circ} \mathrm{C}$.

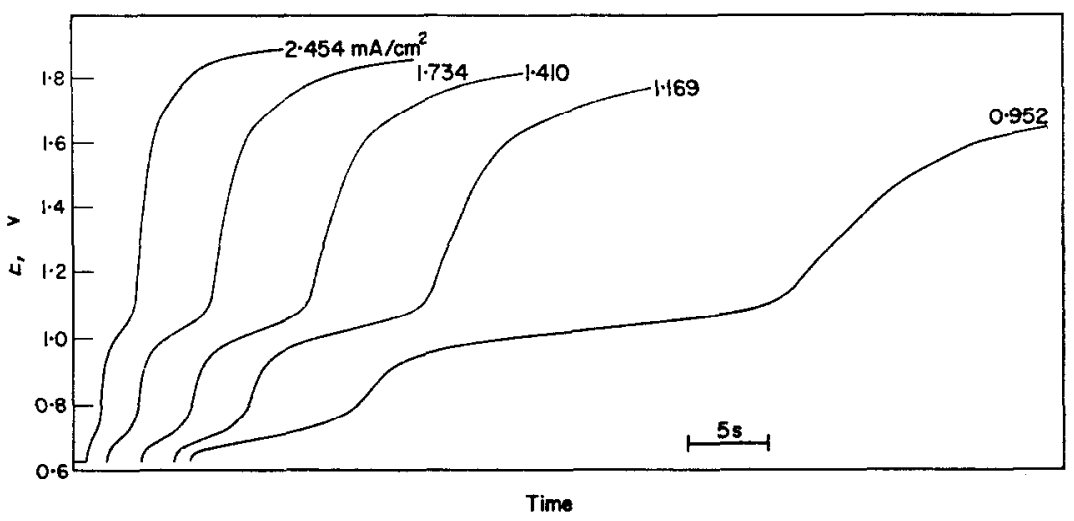

FIG. 3. Anodic potential/time curves.

[NaI], 0.039 M; [NaClO ] $0.80 \mathrm{M} ; 25.0^{\circ} \mathrm{C}$. Ag/AgI reference electrode.

\section{Cathodic curves}

Cathodic curves were obtained with solutions with added iodine. They start with a steep increase of potential up to a value of about $100 \mathrm{mV}$. Then a region of slower rate of increase is observed and finally the potential increases suddenly again, going further up to $1200 \mathrm{mV}$, so that a transition time, $\tau_{c}$, can be defined.

\section{Anodic curves}

The appearance of two chronopotentiometric waves has been systematically observed during the anodic experiments, when using the solutions containing plain iodide as well as with the solutions with iodine. Each wave is defined by its own transition time, $\tau_{1}$ and $\tau_{2}$, respectively. 


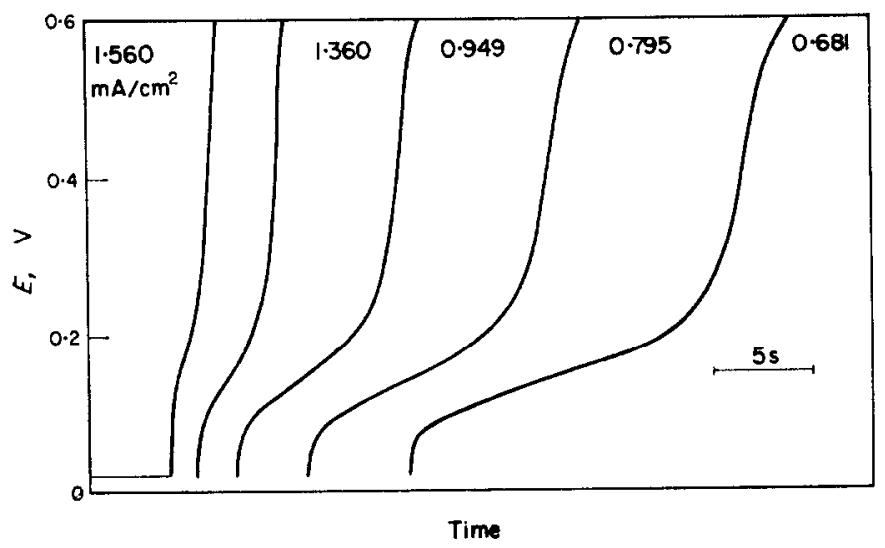

Fro. 4. Cathodic potential/time curves.

$\left[\mathrm{I}_{2}\right], 0.00905 \mathrm{M} ;[\mathrm{NaI}], 0.0132 \mathrm{M} ;\left[\mathrm{NaClO}_{4}\right], 0.40 \mathrm{M} ; 25.0^{\circ} \mathrm{C}$.

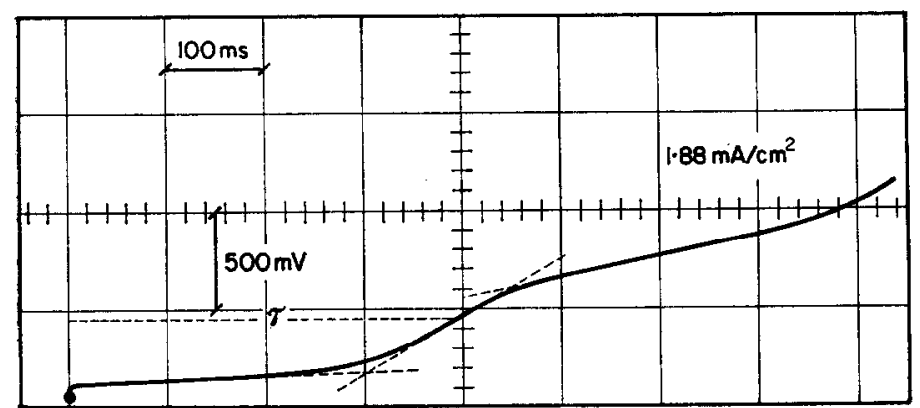

Fig. 5. Oscillographic trace of a cathodic run.

$\left[\mathrm{I}_{2}\right], 0.00394 \mathrm{M} ;[\mathrm{NaI}], 0.0144 \mathrm{M} ;\left[\mathrm{NaClO}_{4}\right], 0.80 \mathrm{M} ; 25.0^{\circ} \mathrm{C}$.

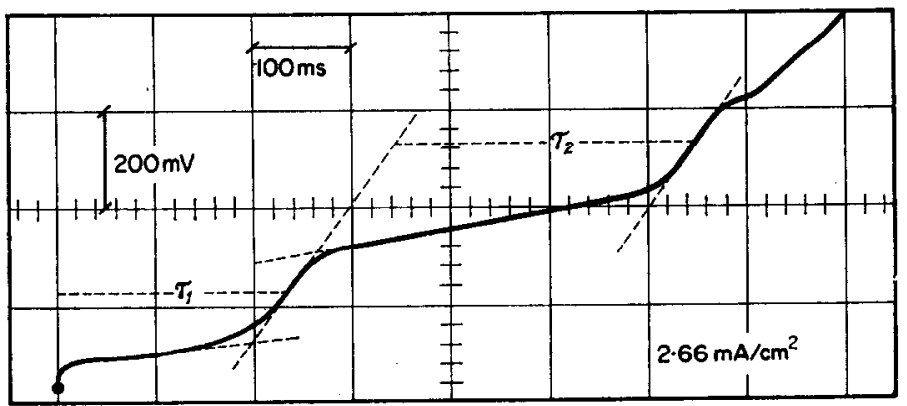

Fio. 6. Oscillographic trace of an anodic run.

[NaI], 0.0206 M; [NaClO ], 0.80 M; 25.0 $0^{\circ} \mathrm{C}$. Ag/AgI reference electrode. 
After the first anodic wave was traced with solutions containing iodide, an emf of about $620 \mathrm{mV}$ between the working electrode and the reference electrode was established, this becoming the initial potential of the following experiments. This was due to the formation of tri-iodide ion during the anodic reaction in those solutions, with the formation of the redox couple iodide-tri-iodide on the platinum electrode.

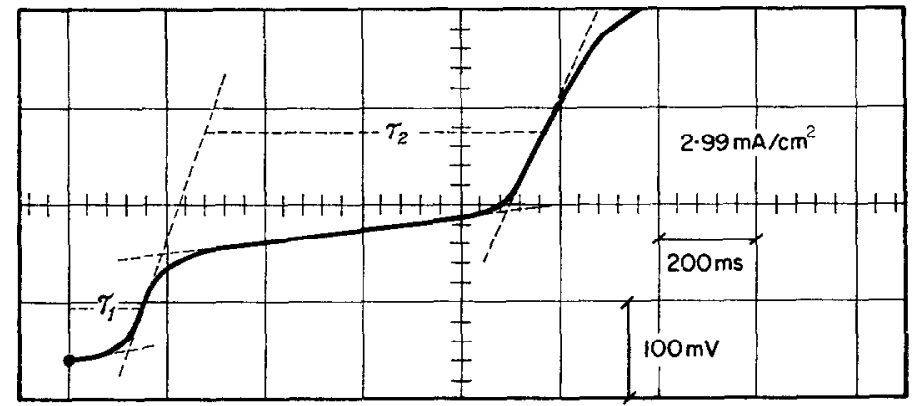

FIG. 7. Oscillographic trace of an anodic run.

[NaI], 0.0185 M; $\left[\mathrm{NaClO}_{4}\right], 0.80 \mathrm{M} ; 25.0^{\circ} \mathrm{C}$. Ag/AgI reference electrode.

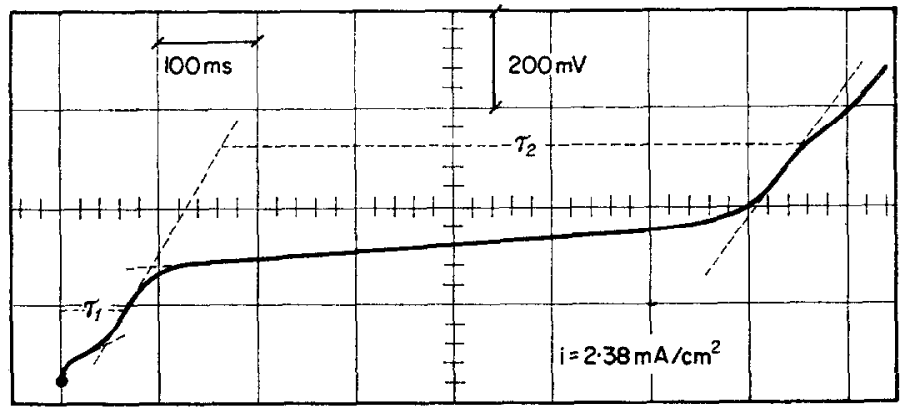

Fig. 8. Oscillographic trace of an anodic run.

$\left[\mathrm{I}_{2}\right], 0.0082 \mathrm{M} ;[\mathrm{NaI}], 0.0122 \mathrm{M} ;\left[\mathrm{NaClO}_{4}\right], 0.80 \mathrm{M} ; 25.0^{\circ} \mathrm{C}$.

\section{INTERPRETATION}

\section{Determination of the transition time}

A simplified theoretical analysis of a potential/time curve at constant current indicates that the curve should involve an initial instantaneous build-up of potential until the potential for the discharge of a particular ionic species is reached. When this occurs, a net plateau should appear in the trace, where the potential changes according to the equations deduced in chronopotentiometry. ${ }^{12}$ Once the reacting species on the electrode surface has been depleted, a time $\tau$ has elapsed and the potential should again change instantaneously, reaching a value where the discharge of another species or of the solvent itself takes place.

This behaviour is not, however, actually observed in the experimental curves, either because there is interference by subsequent reactions, or through additional phenomena occurring at the interphase, which were not properly taken into account in the simplified theory. Therefore, a correction of the values of the transition times for the time required to charge the electrical double layer is occasionally done, as 
indicated in the literature. ${ }^{13}$ The non-instantaneous potential change occurring when the reacting species on the electrode surface is depleted introduces some uncertainty in the determination of the transition times. Furthermore, if the electrode process is irreversible, distortion of the curves (compared to those of an ideal reversible process) might exist.

To determine transition times, various graphical methods having a certain empirical basis have been proposed, each one being justified from different points of view. Those methods, however, lead to non-coincident results when applied to a particular reaction. ${ }^{14}$

In the present case, the transition times were evaluated as indicated by Reinmuth, ${ }^{15}$ Delahay, ${ }^{12}$ Kuwana $^{16}$ and Mayer and Lange. ${ }^{17}$ The last treatment yields the best agreement when the results are compared with those previously obtained for the same reaction on the platinum rotating disk electrode. ${ }^{8}$

\section{Cathodic waves}

There is a dependence of the half-wave potential $E_{1 / 2}$ of the cathodic waves on current density, and the potential/time curves approach the behaviour of a totally irreversible electrode reaction. Cathodic waves can be treated in terms of the equation developed by Berzins and Delahay, ${ }^{18}$

$$
E=\frac{R T}{\alpha n_{\mathrm{a}} F} \ln \frac{n F C_{0}{ }^{0} k_{0}}{i}+\frac{R T}{\alpha n_{\mathrm{a}} F} \ln \left[1-\left(\frac{t}{\tau_{\mathrm{c}}}\right)^{1 / 2}\right],
$$

where $E$ is the electrode potential, $k_{0}$ is the rate constant for $E=0, n$ is the number of electrons involved in the reduction of the substance, $i$ is the current density, $C_{0}{ }^{\circ}$ is the concentration of the reacting species, $n_{\mathrm{a}}$ is the number of electrons involved in the activation step, $\alpha$ is the transfer coefficient for the electrode process and $t$ the time elapsed to reach the electrode potential. Other symbols have their usual meanings.

Cathodic waves plotted according to (1) are shown in Fig. 9. They correspond to the following over-all cathodic reaction,

$$
\mathrm{I}_{3}^{-}+2 \mathrm{e}=3 \mathrm{I}^{-} \text {. }
$$

The kinetic parameters evaluated from the cathodic waves, as well as the diffusion coefficients of tri-iodide ion calculated from Sand's equation, ${ }^{12}$ are assembled in Table 1.

\section{Anodic waves}

The anodic curves systematically exhibit two chronopotentiometric waves which may be considered either as dependent or independent from each other, according to the nature of the electrode process. The treatment of the first anodic wave can be done in terms of a single electrochemical reaction, but for the second wave the situation is more difficult.

If we are dealing with a substance which is oxidized in two steps, involving respectively $n_{1}$ and $n_{2}$ electrons, the following relationship between the corresponding transition times, $\tau_{1}$ and $\tau_{2}$ should be found:

$$
\tau_{2}=\tau_{1}\left[2 \frac{n_{2}}{n_{1}}+\left(\frac{n_{2}}{n_{1}}\right)^{2}\right] .
$$




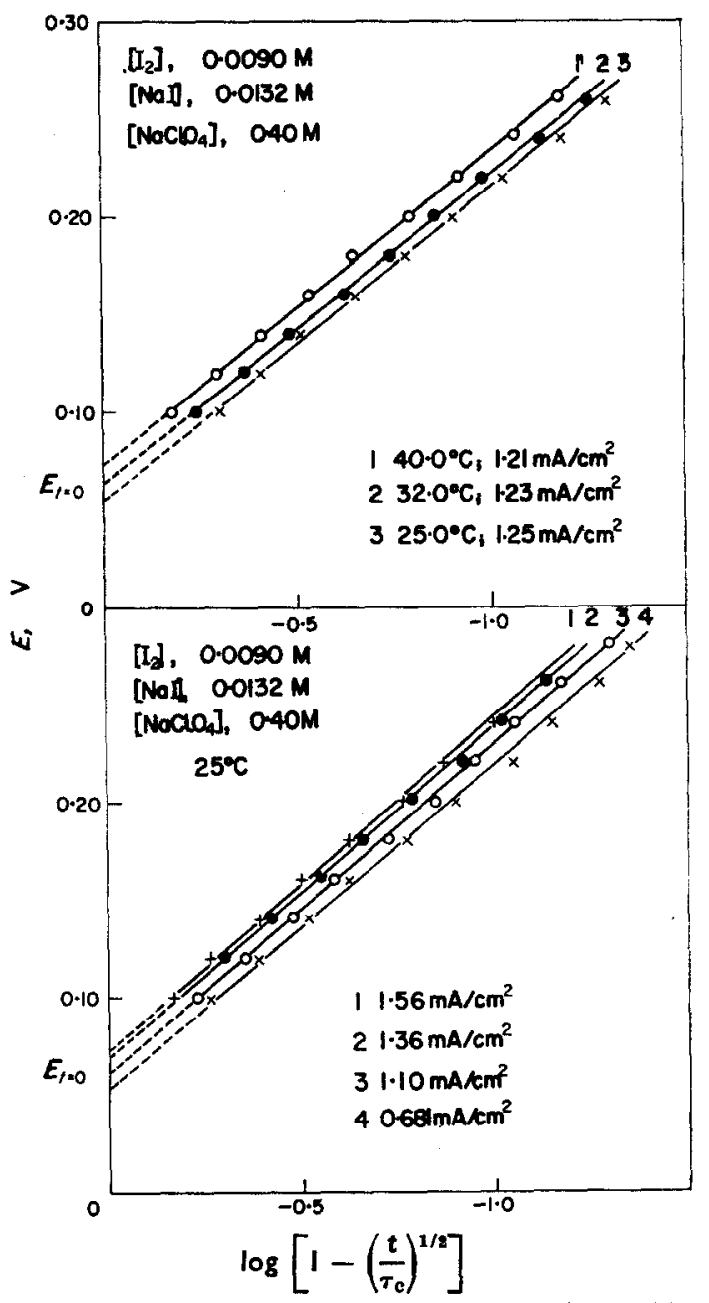

Fig. 9. Plot of cathodic waves according to (1).

Table 1. Cathodic runs

\begin{tabular}{|c|c|c|c|c|c|c|c|}
\hline \multicolumn{4}{|c|}{$\left[\mathrm{I}_{\mathrm{s}}^{-}\right], 0.905 \times 10^{-2} \mathrm{M}$} & \multicolumn{2}{|c|}{ [NaI], 0.0132 M; } & \multicolumn{2}{|c|}{$\left[\mathrm{NaClO}_{4}\right], 0.402 \mathrm{M}$} \\
\hline $\begin{array}{c}i \times 10^{3} \\
\mathrm{~A} / \mathrm{cm}^{2}\end{array}$ & $\begin{array}{l}r \\
\mathrm{~s}\end{array}$ & $\begin{array}{c}T \\
{ }^{\circ} \mathrm{C}\end{array}$ & $\begin{array}{r}i \tau^{1 / 2} \times 10^{2} \\
\mathrm{As}^{1 / 2} / \mathrm{cm}^{2}\end{array}$ & $\underset{\mathrm{V}}{E_{1 / 2}}$ & $\begin{array}{c}D \times 10^{6} \\
\mathrm{~cm}^{2} / \mathrm{s}\end{array}$ & $\alpha n$ & $\begin{array}{c}k_{0} \times 10^{c} \\
\mathrm{~cm} / \mathrm{s}\end{array}$ \\
\hline $\begin{array}{l}0.681 \\
0.795 \\
0.949 \\
1.115 \\
1.360\end{array}$ & $\begin{array}{r}16 \cdot 85 \\
12 \cdot 15 \\
8 \cdot 15 \\
5 \cdot 90 \\
3 \cdot 40\end{array}$ & $\begin{array}{l}25 \cdot 0 \\
25 \cdot 0 \\
25 \cdot 0 \\
25 \cdot 0 \\
25 \cdot 0\end{array}$ & $\begin{array}{l}2 \cdot 80 \\
2.74 \\
2.71 \\
2.79 \\
2.66\end{array}$ & $\begin{array}{l}0 \cdot 110 \\
0 \cdot 120 \\
0 \cdot 120 \\
0 \cdot 125 \\
0 \cdot 135\end{array}$ & $\begin{array}{l}\mathbf{3} \cdot \mathbf{3 1} \\
\mathbf{3} \cdot 17 \\
\mathbf{3} \cdot 10 \\
\mathbf{3} \cdot 28 \\
\mathbf{3} \cdot 00\end{array}$ & $\begin{array}{l}0.43 \\
0.40 \\
0.40 \\
0.36 \\
0.40\end{array}$ & $\begin{array}{l}1.13 \\
1.12 \\
1.56 \\
2.55 \\
2.86\end{array}$ \\
\hline $\begin{array}{l}0.721 \\
0.865 \\
1.030\end{array}$ & $\begin{array}{r}15 \cdot 40 \\
11 \cdot 00 \\
7.50\end{array}$ & $\begin{array}{l}32.0 \\
32.0 \\
32.0\end{array}$ & $\begin{array}{l}2 \cdot 84 \\
2 \cdot 87 \\
2 \cdot 82\end{array}$ & $\begin{array}{l}0.110 \\
0.105 \\
0.110\end{array}$ & $\begin{array}{l}3.38 \\
3.46 \\
3.35\end{array}$ & $\begin{array}{l}0.38 \\
0.39 \\
0.38\end{array}$ & $\begin{array}{l}1.92 \\
2 \cdot 13 \\
2.41\end{array}$ \\
\hline $\begin{array}{l}0.804 \\
0.980 \\
1.130\end{array}$ & $\begin{array}{r}14.50 \\
9 \cdot 15 \\
6.60\end{array}$ & $\begin{array}{l}40.0 \\
40.0 \\
40.0\end{array}$ & $\begin{array}{l}3.06 \\
2.96 \\
2.90\end{array}$ & $\begin{array}{l}0.090 \\
0 \cdot 110 \\
0 \cdot 130\end{array}$ & $\begin{array}{l}3.96 \\
3.69 \\
3.53\end{array}$ & $\begin{array}{l}0.39 \\
0.38 \\
0.37\end{array}$ & $\begin{array}{l}1 \cdot 99 \\
2 \cdot 17 \\
2 \cdot 48\end{array}$ \\
\hline \multicolumn{4}{|c|}{$\left[\mathrm{I}_{3}-\right], 0.200 \times 10^{-2} \mathrm{M}$} & \multicolumn{2}{|c|}{ [NaI], 0.0101 M; } & \multicolumn{2}{|c|}{$\left[\mathrm{NaClO}_{4}\right], 0.800 \mathrm{M}$} \\
\hline $\begin{array}{l}0.217 \\
0.410\end{array}$ & $\begin{array}{l}2.50 \\
0.72\end{array}$ & $\begin{array}{l}25.0 \\
25.0\end{array}$ & $\begin{array}{l}0.343 \\
0.350\end{array}$ & $\begin{array}{l}0.075 \\
0.100\end{array}$ & $\begin{array}{l}3.20 \\
3.35\end{array}$ & - & - \\
\hline
\end{tabular}


According to (2), the ratio $\tau_{1} / \tau_{2}$ approaches definite constant values depending on the magnitudes of $n_{1}$ and $n_{2}$. The experimental results, however, indicate that the transitiontime ratio is not a constant, but changes from one solution to another. Consequently, the over-all anodic process is assumed to consist of two independent processes which are connected phenomenologically through the influence of the flux of the first reacting species upon the concentration of the second one, due to the boundary conditions of Fick's law. The first reaction involves the oxidation of iodide ion and the second the oxidation of tri-iodide ion.

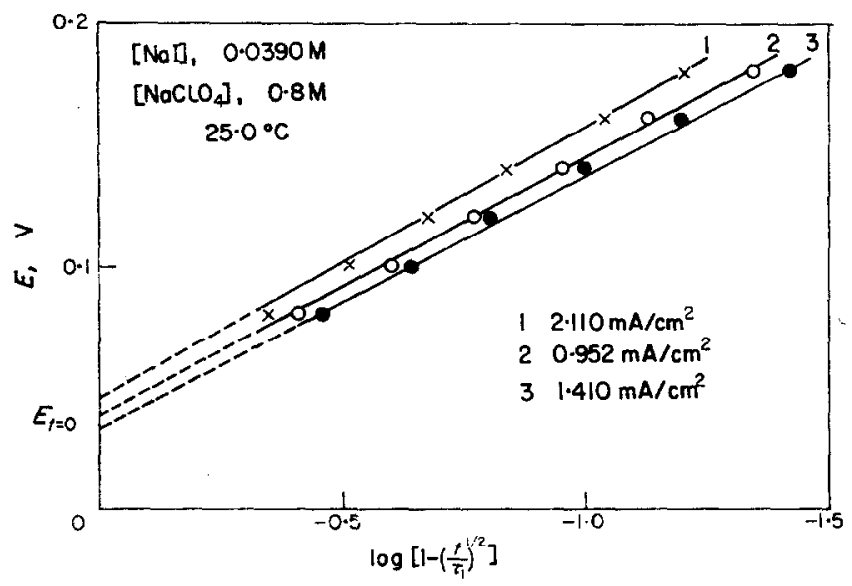

FIG. 10. Plot of first anodic waves as irreversible waves.

Then, the concentration of the second reacting species should depend on $\tau_{1}$ and $\tau_{2}$, according to

$$
C_{0,2}\left(0, t^{\prime}\right)=C_{0,2}^{0}-\frac{2 i}{\pi^{1 / 2} n_{2} F D_{2}^{1 / 2}}\left[\left(\tau_{1}+t^{\prime}\right)^{1 / 2}-\tau_{1}^{1 / 2}\right]
$$

where $D$ is the diffusion coefficient of the reacting species and $t^{\prime}$ is a new scale of time starting at $\tau_{1}$,

$$
t^{\prime}=t-\tau_{1} \text {. }
$$

As the transition time is determined by the condition $C_{0}\left(t^{\prime}, \tau_{2}\right)=0$, from (3) we obtain

$$
\left(\tau_{1}+\tau_{2}\right)^{1 / 2}-\tau_{1}^{1 / 2}=\frac{\pi^{1 / 2} n_{2} F D_{2}^{1 / 2} C_{0,2}^{0}}{2 i} .
$$

Finally, the equation relating the electrode potential with time for a reversible process is

$$
E=E_{1 / 2}+\frac{R T}{n_{2} F} \ln \frac{\left[\left(\tau_{1}+\tau_{2}\right)^{1 / 2}-\tau_{1}^{1 / 2}\right]-\left[\left(\tau_{1}+t^{\prime}\right)^{1 / 2}-\tau_{1}^{1 / 2}\right]}{\left[\left(\tau_{1}+t^{\prime}\right)^{1 / 2}-\tau_{1}^{1 / 2}\right]},
$$

and for a totally irreversible process

$$
E=\frac{R T}{\alpha n_{\mathrm{a}} F} \ln \frac{n_{2} F C_{0,2}^{0} k_{2}^{0}}{i}+\frac{R T}{\alpha n_{\mathrm{a}} F} \ln \left\{1-\frac{\left[\left(\tau_{1}+t^{\prime}\right)^{1 / 2}-\tau_{1}^{1 / 2}\right]}{\left[\left(\tau_{1}+\tau_{2}\right)^{1 / 2}-\tau_{1}^{1 / 2}\right]}\right\} .
$$

No appreciable dependence of the half-wave potentials on current density is observed either with the solutions containing plain iodide or those with the addition of iodine, as was the case for the cathodic reaction. As shown in Figs. 10 and 11, the 
M. C. Giordano, J. C. Bazán and A. J. Arvía

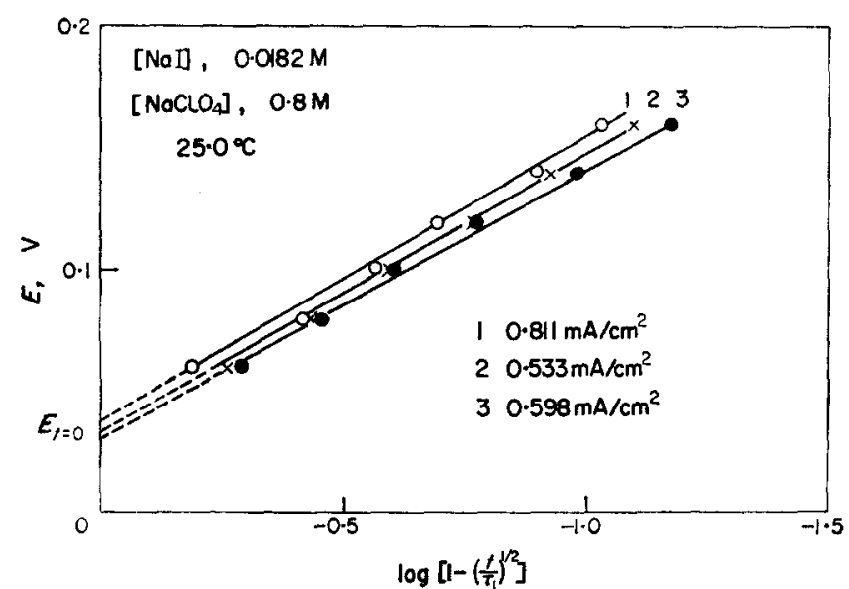

Fig. 11. Plot of first anodic waves as irreversible wavcs.

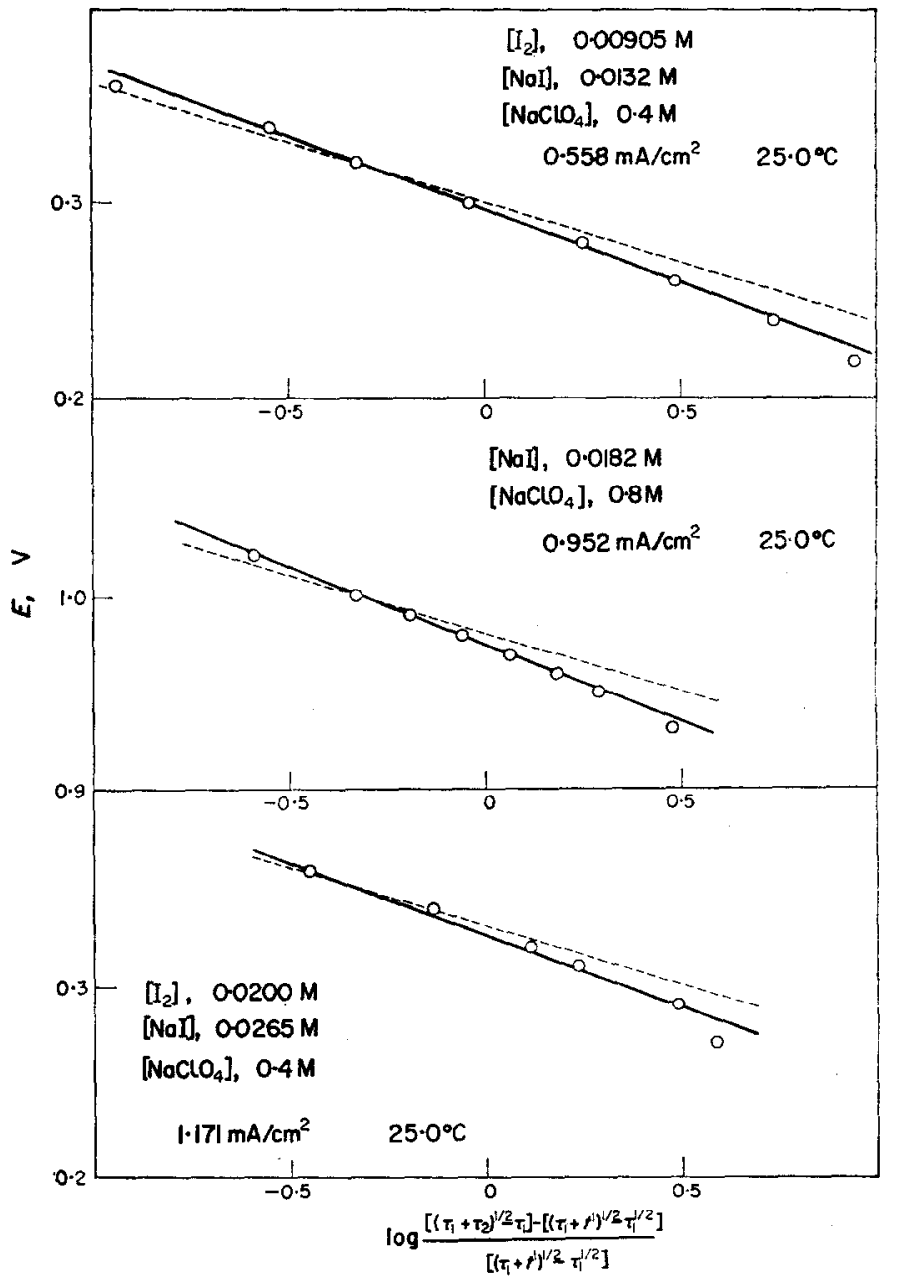

Fio. 12. Second anodic waves plotted according to (6). Dotted line corresponds to a slope of $59 \cdot 16 \mathrm{mV}$. 
first anodic wave can be treated as an irreversible wave. The application of (6) for a reversible process to the second anodic wave yields a fairly acceptable straight line having a slope of about $70 \mathrm{mV}$ at $25^{\circ} \mathrm{C}$, as shown in Fig. 12.

The diffusion coefficients calculated from the first and second anodic waves should correspond, respectively, to iodide and tri-iodide ions. The anodic reactions are

and

$$
3 \mathrm{I}^{-}=\mathrm{I}_{3}^{-}+2 \mathrm{e}
$$

$$
2 \mathrm{I}_{3}-=3 \mathrm{I}_{2}+2 \mathrm{e} \text {. }
$$

For the first step $n$ is $2 / 3$ and for the second, 1 . The diffusion coefficients obtained from the cathodic wave coincide with those calculated from the second wave, by application of (5). Kinetic parameters related to the anodic reactions are assembled in Table 2.

\begin{tabular}{|c|c|c|c|c|c|c|c|c|}
\hline \multicolumn{3}{|c|}{$\left[\mathrm{I}_{2}\right], 2.58 \times 10^{-8} \mathrm{M}$} & \multicolumn{3}{|c|}{$\left[\mathrm{I}^{-}\right], 5.00 \times 10^{-\mathrm{d}} \mathrm{M}$} & \multicolumn{3}{|c|}{$\left[\mathrm{NaClO}_{4}\right], 0.402 \mathrm{M}$} \\
\hline $\begin{array}{c}i \times 10^{8} \\
\mathrm{~A} / \mathrm{cm}^{8}\end{array}$ & $\begin{array}{c}T_{1} \\
\mathrm{~s}\end{array}$ & $\underset{\mathrm{V}}{\left(E_{1 / 2}\right)_{1}}$ & $\begin{array}{c}D_{1} \times 10^{6} \\
\mathrm{~cm}^{2} / \mathrm{s}\end{array}$ & $\begin{array}{l}\tau_{2} \\
\mathrm{~s}\end{array}$ & $\left(E_{1 / 2}\right)_{2}$ & $\tau_{2} / \tau_{1}$ & $\begin{array}{c}D_{2} \times 10^{6} \\
\mathrm{~cm}^{2} / \mathrm{s}\end{array}$ & Reference \\
\hline $\begin{array}{l}3.92 \\
3.64 \\
2.91 \\
2 \cdot 10 \\
1.38\end{array}$ & $\begin{array}{l}0.024 \\
0.030 \\
0.047 \\
0.070 \\
0.200\end{array}$ & $\begin{array}{l}0.065 \\
0.070 \\
0.060 \\
0.050 \\
0.050\end{array}$ & $\begin{array}{l}7 \cdot 0 \\
7 \cdot 3 \\
7 \cdot 3 \\
6 \cdot 0 \\
7 \cdot 1\end{array}$ & $\begin{array}{c}0.047 \\
0.055 \\
0.089 \\
0 \cdot 147 \\
-\end{array}$ & $\begin{array}{c}0.265 \\
0.275 \\
0.260 \\
0.255 \\
-\end{array}$ & $\begin{array}{l}1.96 \\
1.83 \\
1.89 \\
2.10 \\
-\end{array}$ & $\begin{array}{l}3.8 \\
3.9 \\
3.9 \\
3.7 \\
-\end{array}$ & $\mathrm{Pt} / \mathrm{I}_{\mathbf{8}}{ }^{-}, \mathrm{I}^{-}$ \\
\hline \multicolumn{3}{|c|}{$\left[I_{2}\right], 4.0 \times 10^{-8} \mathrm{M}$} & \multicolumn{3}{|c|}{$\left[\mathrm{I}^{-}\right], 20.6 \times 10^{-3} \mathrm{M}$} & \multicolumn{3}{|c|}{$\left[\mathrm{NaClO}_{4}\right], 0.800 \mathrm{M}$} \\
\hline $\begin{array}{l}2.66 \\
0.92\end{array}$ & $\begin{array}{l}0.23 \\
1.92\end{array}$ & $\begin{array}{l}0.675 \\
0.675\end{array}$ & $\begin{array}{l}6 \cdot 7 \\
6 \cdot 8\end{array}$ & $\begin{array}{r}0.30 \\
-\end{array}$ & $\begin{array}{c}0.935 \\
-\end{array}$ & $1 \cdot 31$ & $\begin{array}{l}3 \cdot 7 \\
-\end{array}$ & $\begin{array}{c}\mathrm{Ag} / \mathrm{AgI} / \mathrm{I}^{-} \\
\mathrm{Ag} / \mathrm{AgI} / \mathrm{I}^{-}\end{array}$ \\
\hline \multicolumn{3}{|c|}{$\left[\mathrm{I}_{2}\right], 8.2 \times 10^{-3} \mathrm{M}$} & \multicolumn{3}{|c|}{$\left[\mathrm{I}^{-}\right], 12.22 \times 10^{-3} \mathrm{M}$} & \multicolumn{3}{|c|}{$\left[\mathrm{NaClO}_{4}\right], 0.800 \mathrm{M}$} \\
\hline $2 \cdot 38$ & 0.065 & 0.035 & $7 \cdot 1$ & 0.59 & 0.270 & 9.09 & $3 \cdot 7$ & $\mathrm{Pt} / \mathrm{I}_{3}{ }^{-}, \mathrm{I}^{-}$ \\
\hline \multicolumn{3}{|c|}{$\left[\mathrm{I}_{2}\right], 10.6 \times 10^{-3} \mathrm{M}$} & \multicolumn{3}{|c|}{$\left[\mathrm{I}^{-}\right], 18.5 \times 10^{-3} \mathrm{M}$} & \multicolumn{3}{|c|}{$\left[\mathrm{NaClO}_{4}\right], 0.800 \mathrm{M}$} \\
\hline $\begin{array}{l}2.99 \\
1.60\end{array}$ & $\begin{array}{l}0.150 \\
1.60\end{array}$ & $\begin{array}{l}0.615 \\
0.650\end{array}$ & $\begin{array}{l}6 \cdot 7 \\
7 \cdot 2\end{array}$ & $\begin{array}{l}0.78 \\
3.00\end{array}$ & $\begin{array}{l}0.850 \\
0.890\end{array}$ & $\begin{array}{l}5 \cdot 20 \\
5 \cdot 20\end{array}$ & $\begin{array}{l}3 \cdot 7 \\
4 \cdot 0\end{array}$ & $\begin{array}{l}\mathrm{Ag} / \mathrm{AgI} / \mathrm{I}^{-} \\
\mathrm{Ag} / \mathrm{AgI} / \mathrm{I}^{-}\end{array}$ \\
\hline
\end{tabular}

TABle 2. ANODiC RUNS: $25^{\circ} \mathrm{C}$

It should be remarked that results obtained from the first anodic wave are certainly affected by an error larger than that obtained from the cathodic wave, because of the uncertainty of the iodide-ion concentration on the electrode region once a set of consecutive experiments has been performed. This error affects both values of the diffusion coefficient obtained from the anodic curves. It is also worth while to mention that the only reliable diffusion coefficients from the first wave were obtained from the initial experiments with fresh solutions. Thus, the ratio of the diffusion coefficients of iodide to tri-iodide ion in DMSO is nearly the same as in aqueous solutions., ${ }^{1,2,19}$

\section{DISCUSSION}

The results have been interpreted on the basis of the chronopotentiometry equations related to electrochemical reactions having a large or at least a moderate degree of irreversibility, and in this way it is possible to give a satisfactory explanation of the fact that the product $i \tau^{1 / 2}$, for the cathodic reaction, decreases when thecurrent density increases. This effect, as recently pointed out, ${ }^{17}$ is apparently related to some kinetic 
complication. When the electrode process involves no kinetic effects, that product usually increases as the time decreases, due to the charge of the electrical double layer, formation of superficial oxides, variation of the electrode roughness and a different absorption of electroactive species with different electrode potentials. ${ }^{17}$

The over-all picture obtained from chronopotentiometry in the present case shows that the most reliable information comes from the study of the cathodic reaction. A more comprehensive analysis of this reaction can thus be further developed.

First, we notice that the transfer coefficient obtained for the cathodic reaction is larger than that appearing in the corresponding experiments with the rotating disk electrode ${ }^{8}$ and shows a trend to decrease as the electrode potential increases. Correspondingly, the related Tafel slope is smaller than that previously observed but increases, in the present experiments, with current density. This steady increase of Tafel slope in the potential region under consideration can however be predicted when the results are compared with those of the rotating disk electrode, keeping in mind, particularly in this case, the limitations of chronopotentiometry to obtain experimental data in a lower overpotential region, where reliable transition times can be recorded.

In the cathodic experiments done with the rotating disk electrode, it was precisely observed that at low overpotentials, the current/voltage relationship deviated appreciably from a Tafel line, involving a transfer coefficient of $0 \cdot 25$. This indicated that at low overpotentials the transfer coefficient was certainly higher. The deviation is easily accounted for, as in the potential range investigated in chronopotentiometry the rate equation for the activated process should comprise both the anodic and the cathodic terms. If the conclusions drawn from the rotating disk electrode are recalled, the rate-determining step associated with the cathodic reaction can be written

$$
\mathrm{I}_{\mathbf{3}}{ }^{-}+\mathrm{M}+\mathrm{e} \rightarrow \mathrm{M}(\mathrm{I})+2 \mathrm{I}^{-} \text {, }
$$

where $M$ is an active centre on the electrode surface and $M(I)$ is an iodine atom adsorbed on the same surface.

The rate equation is

$$
i=n F\left\{\vec{k}_{\mathrm{IV}} C_{\mathrm{I}_{\mathrm{a}}}-C_{\mathrm{M}} \exp \left[-\frac{\alpha_{0} F \Delta \phi}{R T}\right]-\bar{k}_{\mathrm{IV}} C_{\mathrm{M}(\mathrm{I})} C_{\mathrm{I}^{-}}{ }^{2} \exp \left[\frac{\alpha_{\mathrm{g}} F \Delta \phi}{R T}\right]\right\},
$$

where the $C$ 's are the concentrations of the reacting species at the electrode surface. From (8), when $R T / \alpha F$ is greater than $\Delta \phi$, the anodic term can no longer be neglected in the rate equation and accordingly a deviation from the Tafel law should be observed. $\Delta \phi$ is the potential of the electrode/solution interphase.

From the above discussion it may be concluded that the rate constant $k_{0}$ is lower than that deduced from the rotating disk electrode. ${ }^{8}$ On the other hand the rate constant calculated at the reversible potential from chronopotentiometry increases with potential, achieving, as a limiting value, the rate constant deduced from the rotating disk experiments $\left(k_{0}=6.8 \times 10^{-4} \mathrm{~cm} / \mathrm{s}\right)$.

When the anodic reactions are considered, a greater uncertainty concerning the transition times is quite evident, as already mentioned. Nevertheless the type of analysis formerly done with the cathodic reaction can be extended also to the anodic processes. The uncertainty involved in the first transition time reflects in the magnitude of the second one. Therefore, a comparison with corresponding experiments using the rotating disk electrode is more difficult. 
The analysis of the anodic waves confirms the existence of an appreciable degree of irreversibility even at the low potentials applied here. This effect is clearer for the first wave than for the second. Again recalling the experiments with the rotating disk electrode, the irreversibility of the first wave should correspond to

$$
\mathrm{I}^{-}+\mathrm{M} \rightarrow \mathrm{M}(\mathrm{I})+\mathbf{e},
$$

which was earlier postulated as the rate-determining step to explain former experimental results.

On the contrary, the second anodic wave behaves approximately as a reversible wave, but the corresponding slope, as shown in the figure, is larger than the one expected assuming a reaction involving one electron.

The fact that the second anodic wave appears with a smaller degree of irreversibility than the first is also a consequence of the reaction paths earlier dealt with. The exchange current densities for the second anodic reaction are higher, under similar conditions, than those corresponding to the first. Therefore, it is reasonable to find that the second wave, at lower overpotentials, comes closer to a reversible behaviour than the first wave. The second anodic wave is due to

$$
\mathrm{I}_{3}-\mathbf{M} \rightarrow \mathrm{M}\left(\mathrm{I}_{3}\right)+\mathrm{e} \text {. }
$$

Chronopotentiometry itself is unable to yield in the present circumstances definite information regarding the mechanisms of the iodide-tri-iodide redox system in DMSO on platinum electrodes. The information obtained, however, is consistent with the reaction schemes earlier discussed for the same system, where the contribution of each polarization term could be separated and independently evaluated.

Acknowledgement-The present work was done in part with financial support from the Consejo Nacional de Investigaciones Cientificas y Técnicas of Argentina. M. C. G. thanks the CNICT for the fellowship granted.

\section{REFERENCES}

1. K. J. VeTtER, Z. phys. Chem. 199, 22 (1952); 199, 285 (1952).

2. J. D. RIDDIroRD and A. C. NEWSON, J. electrochem. Soc. 108, 695 (1961).

3. A. C. Newson and J. D. RidDIForD, J. electrochem. Soc. 108, 699 (1961).

4. J. JoRDAN and R. A. JAVICK, Electrochim. Acta 6, 23 (1962).

5. I. M. Kolthoff and J. Jordan, J. Am. chem. Soc. 75, 1571 (1953).

6. R. T. Iwamoto, Analyt. Chem. 31, 955 (1959).

7. M. C. Giordano, J. C. BazÁn and A. J. ARvta, Electrochim. Acta 11, 741 (1966).

8. M. C. Giordano, J. C. BazÁn and A. J. ARvia, Electrochim. Acta 11, 1553 (1966).

9. P. Delahay and C. C. MatTaX, J. Am. chem. Soc. 76, 874 (1954).

10. M. C. Glordano, J. C. BazÁN and A. J. ARvia, J. inorg. nucl. Chem. 28, 1209 (1966).

11. J. KenträmaA, Acta chem. fenn. B33, 179 (1960).

12. P. Delahay, New Instrumental Methods in Electrochemistry. Interscience, New York (1954).

13. W. H. Rennmuth, Analyt. Chem. 33, 485 (1961).

14. C. D. Russerl and J. M. Peterson, J. electroanal. Chem. 5, 467 (1963).

15. W. H. Reinmuth, Analyt. Chem. 33, 322 (1961).

16. C. D. Russell and J. M. Peterson, J. electroanal. Chem. 5, 471 (1963).

17. J. S. MAYELL and S. H. LANGER, Electrochim. Acta 9, 1411 (1964).

18. T. Berzins and P. Delahay, J. Am. chem. Soc. 75, 4205 (1953).

19. G. EdGaR and S. H. Diggs, J. Am. chem. Soc. 38, 256 (1916). 